\title{
In vitro exposure to very low-level laser modifies expression level of extracellular matrix protein RNAs and mitochondria dynamics in mouse embryonic fibroblasts
}

\author{
Alessandro Giuliani ${ }^{1 *}$, Luca Lorenzini ${ }^{2}$, Marco Alessandri², Roberta Torricella², Vito Antonio Baldassarro², \\ Luciana Giardino ${ }^{1,3}$ and Laura Calzàa,3
}

\begin{abstract}
Background: Low-level lasers working at 633 or $670 \mathrm{~nm}$ and emitting extremely low power densities (Ultra Low Level Lasers - ULLL) exert an overall effect of photobiostimulation on cellular metabolism and energy balance. In previous studies, it was demonstrated that ULLL pulsed emission mode regulates neurite elongation in vitro and exerts protective action against oxidative stress.

Methods: In this study the action of ULLL supplied in both pulsed and continuous mode vs continuous LLL on fibroblast cultures (Mouse Embryonic Fibroblast-MEF) was tested, focusing on mitochondria network and the expression level of mRNA encoding for proteins involved in the cell-matrix adhesion.

Results: It was shown that ULLL at $670 \mathrm{~nm}$, at extremely low average power output $\left(0.21 \mathrm{~mW} / \mathrm{cm}^{2}\right)$ and dose $\left(4.3 \mathrm{~mJ} / \mathrm{cm}^{2}\right)$, when dispensed in pulsed mode (PW), but not in continuous mode $(\mathrm{CW})$ supplied at both at very low $\left(0.21 \mathrm{~mW} / \mathrm{cm}^{2}\right)$ and low levels $\left(500 \mathrm{~mW} / \mathrm{cm}^{2}\right)$, modifies mitochondria network dynamics, as well as expression level of mRNA encoding for selective matrix proteins in MEF, e.g. collagen type $1 \mathrm{a} 1$ and integrin a5.
\end{abstract}

Conclusions: We suggest that pulsatility, but not energy density, is crucial in regulating expression level of collagen I and integrin a5 in fibroblasts by ULLL.

Keywords: Ultra Low Level Laser, Neurite elongation, Oxidative stress, Mouse embryonic fibroblast, Matrix protein, Mitochondria dynamic

\section{Background}

The use of Low Density/Power lasers in physical medicine (Low Level Laser Therapy- LLLT) has become a consolidated practice in recent decades. Part of the wide range of therapeutic indications have been validated by meta-analysis studies, such as tendon injuries [1], wound healing [2], pain [3-6], nerve regeneration [7-9]. The main physical characteristics of LLLT are the wavelength range from far-red to near infrared (600-1064 $\mathrm{nm}$ ) and power range from 0.001 to $5 \mathrm{~W} / \mathrm{cm}^{2}$ with an application period of a few seconds to several minutes [10]. Safety

\footnotetext{
*Correspondence: a.giuliani@unibo.it

'Department of Veterinary Medical Sciences, University of Bologna, Via Tolara di Sopra 41/E, 40064 Ozzano Emilia, Bologna, Italy

Full list of author information is available at the end of the article
}

profile [11] and dosage recommendations are available from the World Association for Laser Therapy [12].

Cellular, subcellular and molecular mechanisms underlying the medical effects of LLLT are under intensive investigation, and agreement is emerging that mitochondria are the principal photoacceptors present inside cells $[13,14]$. Moreover, a number of papers reporting in vitro and in vivo studies indicate that the intracellular pathways affected by LLL stimulation include oxidative stressrelated pathways [15], PI3-K/Akt signalling cascade and nuclear receptors [15], NFkB [16] and others [17,18]. These pathways are under active investigation to elucidate the possible mechanism of the therapeutic actions of LLLT, also pursuing the objectives of Evidence Based Medicine. 
More recently, a new class of low-level lasers working at 633 or $670 \mathrm{~nm}$ and emitting extremely low power densities (about $0.15 \mathrm{~mW} / \mathrm{cm}^{2}$ ) has been introduced. These Ultra Low Level Lasers (ULLL) working in pulsed or continuous emission mode are capable of eliciting significant biological effects, possibly via photostimulation [10]. ULLL therapeutic effectiveness on human and animal models has been suggested in osteoarthritis [19], balance disorder when applied on acupoints [20], acute and chronic joint inflammation [21,22], thermal hyperalgesia in rat [23], orthodontic applications [23], cosmetic medicine [24], wound healing [25], etc.

In this study the action of ULLL delivered in both pulsed and continuous mode vs continuous LLL was tested on fibroblast cultures (Mouse Embryonic Fibroblast-MEF), focusing on the expression level of proteins involved in the cell-matrix adhesion. Sub-cellular effects of ULLL pulsed emission mode has been demonstrated in vitro on neurite elongation [26], on cell body shape [27], as protective action from oxidative stress $[10,26]$. As the fibroblasts are the most abundant cellular component of the subcutaneous tissue, these cells are primarily and directly affected by the laser beam during laser therapy, in conditions in which the subcutaneous tissue is the target for (as for wound healing and non invasive body contouring) or is incidentally invested (as for orthopaedic pathologies) by ULLL therapy.

\section{Methods}

MEF cell culture and exposure system

Mouse Embryonic Fibroblasts (MEFs) were prepared at day $12.5-14.5$ as described [28]. Cells were seeded at a density of $1.6 \times 10^{5}$ and $5 \times 10^{3}$ cells/well in a 24 multi-well plate with glass coverslips $2 \mathrm{D}$-Cultrex ${ }^{\odot}$ BME coated for mRNA extraction and ImmunoCytoChemistry (ICC), respectively. MEF were maintained in a humidified atmosphere at $37^{\circ} \mathrm{C}, 5 \% \mathrm{CO}_{2}$ in a medium consisting of DMEM (Dulbecco's Modified Eagle's Medium) (GIBCO), 10\% FBS, 1\% MEM/NEAA (Minimum essential medium/ nonessential amino acids) (GIBCO), $100 \mathrm{IU} / \mathrm{ml}$ Penicillin/ $100 \mu \mathrm{g} / \mathrm{ml}$ Streptomycin (GIBCO). The Biolite ${ }^{\bullet}$ exposure system (Figure 1) consisted of a SANYO DL3149-055A diode with wavelength $=670 \pm 10 \mathrm{~nm}$; peak power $=3$ $\mathrm{mW}$. The following emission modes were used: $\mathrm{CW}=$ Continuous Wave; PW = Double Pulsed Square Wave (Biolite ${ }^{\bullet}$ int. patent). A CW Reference LLL class laser was also included. Emission parameters of all exposure conditions are listed in Table 1 . These power/energy levels lie well outside the limits set by the Arndt-Shulz law for photostimulation [29] and have been discussed in a specific report [10]. The "reference" laser probe (CW Ref) consists of a Continuous Wave Diode with wavelength $=650 \mathrm{~nm}$, and peak power $=50 \mathrm{~mW}$.

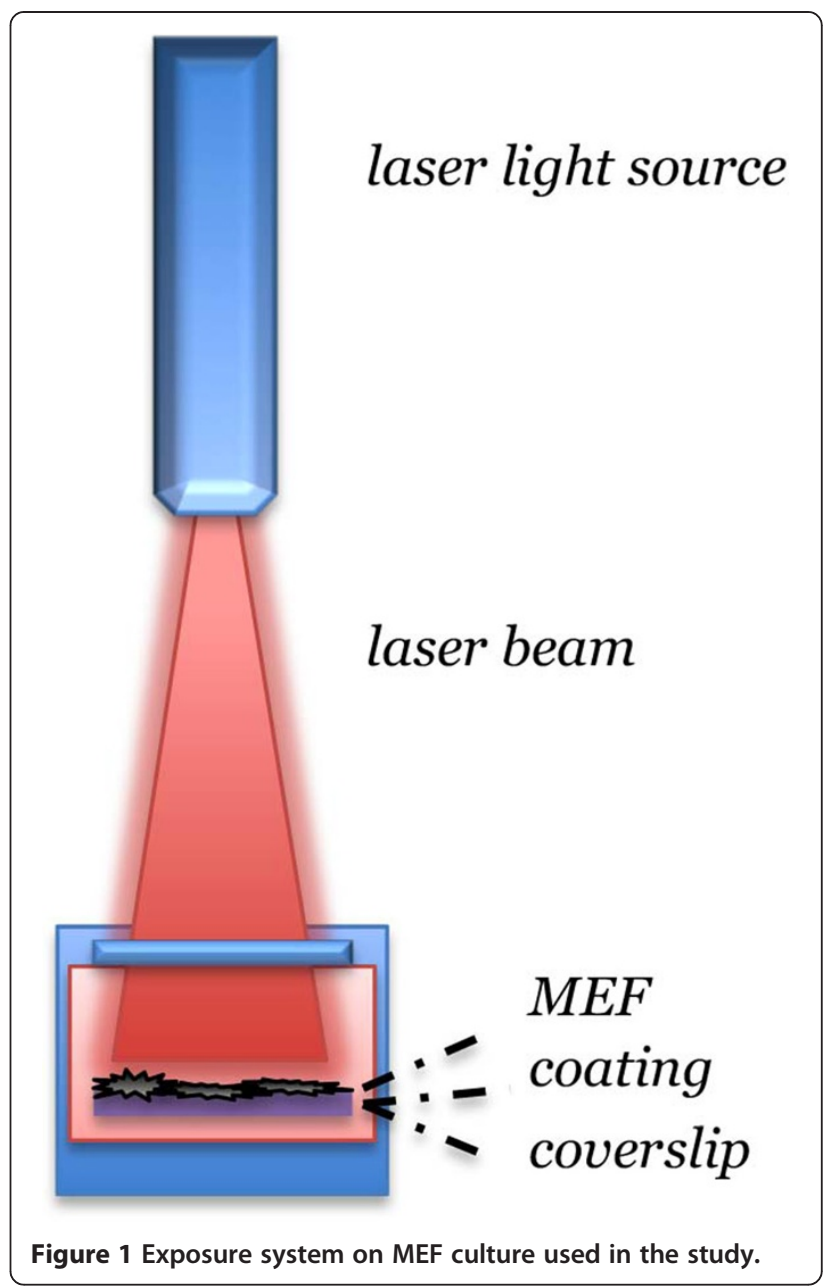

Twenty-four $\mathrm{h}$ after seeding, cells were exposed for 20 " once a day for 3 consecutive days. For immunocytochemistry experiments, in order to investigate mitochondrial network dynamic immediately after laser, cells were fixed after the last laser irradiation. In order to investigate the effect of laser irradiation on mRNA expression level cells were processed $2 \mathrm{~h}$ after last laser irradiation.

\section{Immunocytochemistry, imaging and image analysis}

Indirect immunofluorescence (IF) procedures were used for cytochrome $\mathrm{C}$ (Cyt-C) detection. Cells were washed in PBS and fixed in 4\% paraformaldehyde in 0.1 M Sørensen phosphate buffer for $20 \mathrm{~min}$ at room temperature (RT). Cells were then blocked with 5\% Donkey Normal Serum (Sigma-Aldrich) in 0.3\% PBS/Triton-X 100 (Merck, Darmstadt, Germany) for $1 \mathrm{~h}$ at room temperature, then incubated overnight at $4^{\circ} \mathrm{C}$ in humid atmosphere with the primary antibody (sheep anti-Cyt-C: 1:800; SigmaAldrich) diluted in blocking solution. After rinsing in PBS $(2 \times 10 \mathrm{~min})$, cells were incubated with fluorochromeconjugated secondary antisera (DyLight 488 Donkey Anti-Goat 1: 500; Jackson ImmunoResearch Laboratory) 
Table 1 Laser emission parameters

\begin{tabular}{lllll}
\hline Parameter & Unity & \multicolumn{3}{l}{ Laser emission } \\
\cline { 3 - 5 } & & CW & PW & CW Ref \\
\hline Wavelenght & $\mathrm{nm}$ & 670 & 670 & 650 \\
Modulation & - & none & Pulsed & none \\
& & & $100 \mathrm{~Hz}-1 \%$ & \\
& & & $+1 \mathrm{~Hz} \mathrm{50 \%}$ \\
Spot size & $\mathrm{cm}^{2}$ & 0.07 & 0.07 & 0.10 \\
Peak power & $\mathrm{mW}$ & 3 & 3 & 50 \\
Average power & $\mathrm{mW}$ & 3 & 0.015 & 50 \\
Avg fluence & $\mathrm{mW} / \mathrm{cm} 2$ & 42 & 0.21 & 500 \\
Emission time & $\mathrm{sec}$ & 20 & 20 & 20 \\
Energy & $\mathrm{mJ}$ & 60 & 0.3 & 1,000 \\
Energy density & $\mathrm{mJ} / \mathrm{cm} 2$ & 857 & 4.3 & 7,692 \\
\hline
\end{tabular}

diluted in $0.3 \% \mathrm{PBS} /$ Triton-X 100 for $30 \mathrm{~min}$ at $37^{\circ} \mathrm{C}$. For nuclear staining, cells were first washed in PBS then incubated $15 \mathrm{~min}$ in PBS containing $1 \mu \mathrm{g} / \mathrm{ml}$ Hoechst 33258, $0.2 \%$ Triton-X 100. After rinsing in PBS cells were mounted in $0.1 \%$ glycerol/1,4-phenylendiamine (SigmaAldrich). Negative controls were performed by primary antibody omission.

Analysis was carried out on adherent fibroblasts presenting lamellipodia and filopodia. Fifty cells for each treatment group were analyzed by Nikon Ti-E fluorescence microscope coupled with A1R confocal system (Nikon). A multi-Ar (457/488/514) laser with exciting wavelengths for DyLight 488 was used. Images were acquired by oil-immersion $60 x$ objective (NA 1.4) and a 6x zoom factor, using Nis-Elements AR 3.2 software. Image resolution was $1024 \times 1024$ pixels and optical sections for confocal stacks were 0.125 micrometers. The image frame for mitochondrial network analysis was positioned in the cytoplasmic area of the cell so that at least one side of the frame was in contact with the nucleus. The mitochondria network was sampled as volume surface of Cyt-C-IR objects, created and analyzed on confocal stacks using the $3 \mathrm{D}$ analysis software Imaris (Bitplane AB, Saint Paul, MN, USA). For isosurface creation and measure, images were processed by background subtraction and gaussian smoothing filter, then normalized according to the sampled volume (Figure 2). To distinguish mitochondria from residual background, objects with a volume of less than $0.04 \mu \mathrm{m}^{3}$ were excluded from the analysis, while objects with a volume ranging from 0.04 to $0.1 \mu^{3}$ and were considered as single mitochondria [29].

\section{RNA extraction, retrotranscription and semi-quantitative} real time PCR

Total RNA was extracted using Mini RNAasy Kit (Qiagen, Milan, Italy) and following the manufacturer's specifications. RNAs were subjected to DNase treatment ( $1 \mathrm{U} / \mu \mathrm{l}, 1 \mathrm{x}$ DNase buffer, $2 \mathrm{U} / \mu \mathrm{l}$ ribonuclease inhibitor at $37^{\circ} \mathrm{C}$ for $30 \mathrm{~min}$ ) (Fermentas, Life Sciences, Italy) and mRNAs were retrotranscribed with the enzyme $M$ Moloney murine leukemia virus reverse transcriptase (M-MuLV-RT, 10U $\mu \mathrm{l}$ ) (Fermentas) in the presence of $1 \mathrm{x}$ first strand buffer, $1 \mathrm{mM} \mathrm{d}(\mathrm{NTP}) \mathrm{s}$ (Fermentas), $25 \mathrm{ng} / \mu \mathrm{l}$ Oligo $(\mathrm{dT})_{18}$ primer (Fermentas), incubating at $42^{\circ} \mathrm{C}$ for $60 \mathrm{~min}$.

The mRNA expression analyses were performed using a Real Time PCR (Mx3005P QPCR System, Stratagene, La Jolla, CA, USA) equipped with a $\mathrm{FAM}^{\mathrm{Tm}} / \mathrm{SYBR}^{\odot}$ Green I filter (492 nm excitation-516 $\mathrm{nm}$ emission). The chemistry chosen to perform these PCR experiments was based on SYBR Green I fluorescent detection and each reaction mix consisted of $10 \mathrm{ng}$ of template cDNA, 1x Maxima $^{\text {тм }}$ SYBR Green/ROX qPCR Master Mix (Fermentas) and $0.4 \mu \mathrm{M}$ of both primers (sense and antisense). Specific primers for each gene of interest are summarized in Table 2; among these, GAPDH was considered as housekeeping gene. All primers were obtained from IDT (Coralville, IA, USA). PCR started with 1 cycle at $95^{\circ} \mathrm{C}$ for $10 \mathrm{~min}$, followed by 40 cycles with specific conditions for each primer, as shown in Table 2; at the end of amplification cycles the dissociation curve was constructed following a procedure consisting of first incubating sample at $95^{\circ} \mathrm{C}$ for 1 min to denature the PCR-amplified products, then ramping temperature down to $55^{\circ} \mathrm{C}$ and finally increasing temperature from $55^{\circ} \mathrm{C}$ to $95^{\circ} \mathrm{C}$ at the rate of $0.2^{\circ} \mathrm{C} / \mathrm{s}$, continuously collecting fluorescence intensity over the temperature ramp. The specificity of the amplified product was controlled by the presence of a single peak at the expected melting temperature. Random amplified products were resolved by electrophoresis in a $2.0 \%$ agarose gel stained with ethidium bromide, in order to check the specificity of the PCR reaction. This was confirmed by the presence of a single band of the expected size. A $100 \mathrm{bp}$ DNA ladder (Fermentas) was used as DNA marker. The semi-quantitative analysis of gene expression was performed on the values of the threshold cycle $(\mathrm{Ct})$ obtained for each sample, considering GAPDH as housekeeping gene. Samples were always processed in duplicate. The relative gene expression was calculated with the formula $2^{(-\Delta \Delta \mathrm{Ct})}$, using a defined group as reference $\left(2^{(-\Delta \Delta \mathrm{Ct})}=1\right)$.

\section{Statistical analysis}

Statistical testing was performed with ANOVA followed by Dunnett's multiple comparisons test. A probability level of $\mathrm{p}<0.05$ was considered to be statistically significant.

\section{Results}

In these experiments, the fibroblasts were grown on Cultrex ${ }^{\oplus}$-coated slides. Cultrex ${ }^{\bullet}$ is a soluble form of 

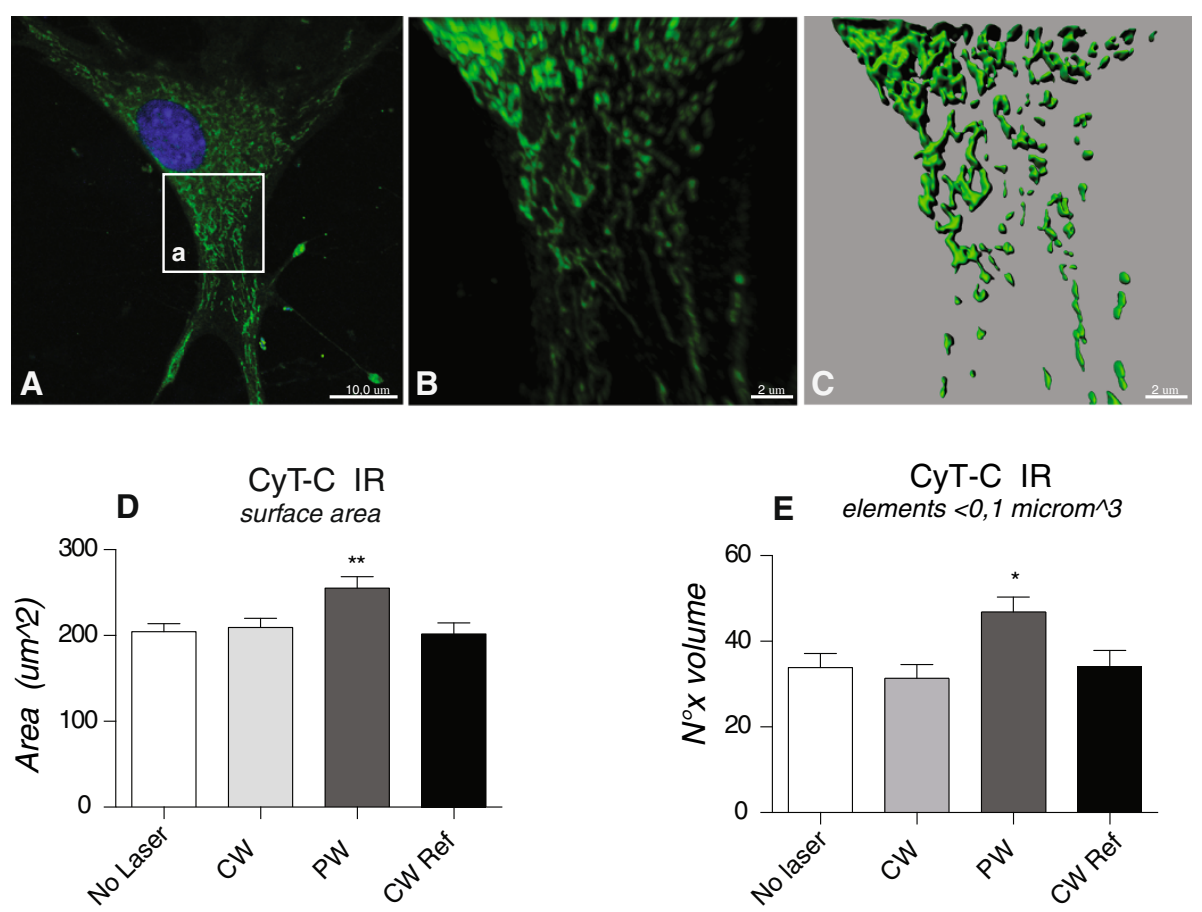

Figure 2 Mitochondria dynamic analysis in MEF under the different experimental conditions. A. Confocal image of Cyt-C-IR fibroblast. The square in a) indicates the sampled area. B-C. Image processing: B) Background subtraction and gaussian smoothing filter were applied using Imaris software (BitPlane); C) Mitochondrial isosurface reconstruction was obtained with 3D analysis software Imaris. D. Quantitative analysis of total Cyt-C-IR isosurface area. There are no differences between unexposed cells and cells exposed to CW mode, while there is an increase in the values of the total isosurfaces of the cells exposed to PW. Statistical analysis: One way ANOVA, Dunnett's multiple comparison test ${ }^{* *} p<0.01$. E. Number of CYT-C IR elements with a volume included between 0.04 and 0.1 micron^3. There is an increase in the number of mitochondria in cells exposed to PW Mode. Statistical analysis: one way ANOVA, Dunnett's multiple comparison test ${ }^{*} \mathrm{p}<0.05$.

Table 2 Primers and conditions used for real time PCR reactions

\begin{tabular}{|c|c|c|c|}
\hline Gene & Acc. $N^{\circ}$ & Sequences $(x-y)$ & Conditions \\
\hline \multirow[t]{3}{*}{ GAPDH } & M17701 & 5-GGCAAGTTCAATGGCACAGTCAAG-3 & $95^{\circ} \mathrm{C} 30 \mathrm{~s}$ \\
\hline & & 5-ACATACTCAGCACCAGCATCACC-3 & $60^{\circ} \mathrm{C} 30 \mathrm{~s}$ \\
\hline & & & 40 cycle \\
\hline \multirow[t]{3}{*}{ Laminin a 1} & NM_008480.2 & 5-GGGATGAAGAAGCAAAGCAACT-3 & $95^{\circ} \mathrm{C} 30 \mathrm{~s}$ \\
\hline & & 5-CTCCTTTGCAACACTGCTGTC-3 & $60^{\circ} \mathrm{C} 45 \mathrm{~s}$ \\
\hline & & & 40 cycle \\
\hline \multirow[t]{3}{*}{ Cadherin 1} & NM_009864.2 & 5-CGACCGGAAGTGACTCGAAA-3 & $95^{\circ} \mathrm{C} 30 \mathrm{~s}$ \\
\hline & & 5-AACCACTGCCCTCGTAATCG-3 & $60^{\circ} \mathrm{C} 45 \mathrm{~s}$ \\
\hline & & & 40 cycle \\
\hline \multirow[t]{3}{*}{ Integrin a5 } & NM_010577.3 & 5-CTCTGTGGCTGTGGGTGAAT-3 & $95^{\circ} \mathrm{C} 30 \mathrm{~s}$ \\
\hline & & 5-CGAAGTAGGAGGCCATCTGTT-3 & $60^{\circ} \mathrm{C} 45 \mathrm{~s}$ \\
\hline & & & 40 cycle \\
\hline \multirow[t]{3}{*}{ Collagen type I a1 } & NM_007742.3 & 5-TCAGCTITGTGGACCTCCG-3 & $95^{\circ} \mathrm{C} 30 \mathrm{~s}$ \\
\hline & & 5-GGACCCTTAGGCCATTGTGT-3 & $60^{\circ} \mathrm{C} 45 \mathrm{~s}$ \\
\hline & & & 40 cycle \\
\hline
\end{tabular}


basement membrane, the continuous sheets of specialized extracellular matrix that form an interface between cells and their adjacent stroma. The Cultrex ${ }^{\odot}$ composition includes laminin, collagen IV, entactin, and heparin sulfate proteoglycan. Thus, this culturing condition provides an in vitro adhesion surface close to the physiological microenvironment of fibroblasts.

In order to confirm that the ULLL irradiation used in this study impacts on mitochondria, e.g. the wellestablished photoaceptor organell, in a first set of experiments the mitochondria net based on Cyt-C immunoreactive signal were analyzed. An increase was found in the total isosurfaces in cells exposed to PW compared to both CW and CW Ref mode ( $\mathrm{p}=0.0061)$ (Figure 2). This suggests that the number of isolated mitochondria increases under this irradiation condition, as confirmed by the count of elements having volume lying between 0.04 and $0.1 \mu \mathrm{m}^{3}(\mathrm{p}=0.0195)$.

In view of the impact of therapeutic low-level laser irradiation on the subcutaneous tissue and resident cells, in a second set of experiments the expression level of mRNA encoding for extracellular matrix and adhesion proteins in MEF was analysed (Figure 3). PW induces an increase in integrin $\alpha 5(\mathrm{p}=0.0192)$ and collagen type $1 \alpha 1$ $(\mathrm{p}=0.0263)$ mRNAs expression level, while it had no effect on laminin $\alpha 1$ and cadherin 1 .

\section{Discussion}

The present study shows that ULLL at $670 \mathrm{~nm}$, at extremely low average power output $\left(0.21 \mathrm{~mW} / \mathrm{cm}^{2}\right)$ and dose $\left(4,3 \mathrm{~mJ} / \mathrm{cm}^{2}\right)$, when dispensed in pulsed mode (PW), but not in continuous mode (CW) delivered both at very low $\left(0.21 \mathrm{~mW} / \mathrm{cm}^{2}\right)$ and at low levels $\left(500 \mathrm{~mW} / \mathrm{cm}^{2}\right)$, modifies mitochondria network dynamics, and expression level of mRNA encoding for selective matrix proteins in MEF, e.g. collagen type $1 \alpha 1$ and integrin $\alpha 5$. Notably, continuous wave light, which is the gold standard for all LLLT applications [30], is not effective on these biological targets. It was thus confirmed that pulsed photostimulation rather than dose is a key characteristic of biologically effective ULLL therapy.

Pulsed light could interfere with some fundamental frequencies (2.5-10.0 Hz range) and/or processes that exist in biological systems, including photodissociation in cytochrome c oxidase in mitochondria [31,32]. Mitochondria are in fact recognized as the principal intracellular
A

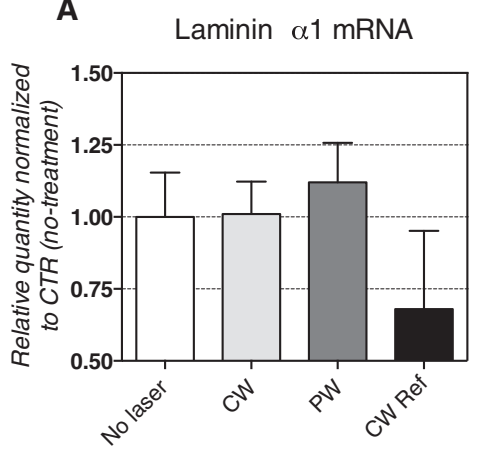

C

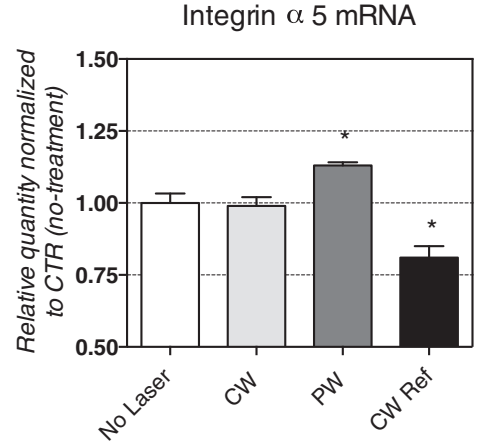

B

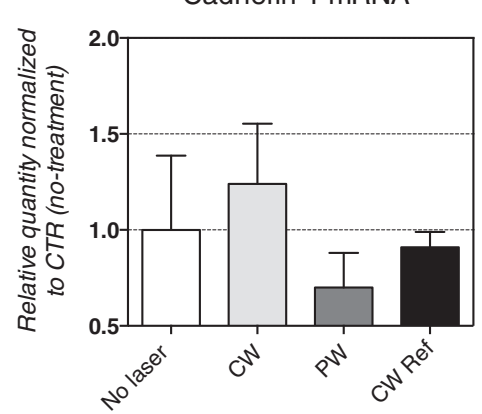

D Collagen type I $\alpha 1 \mathrm{mRNA}$

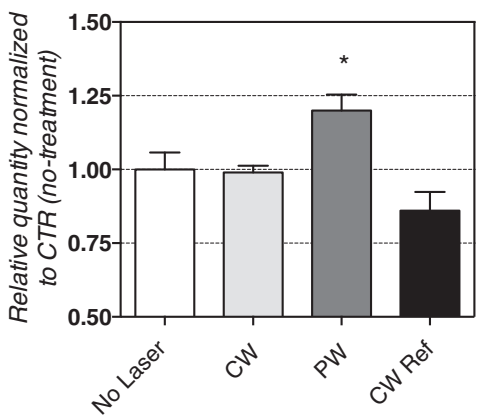

Figure 3 PCR analysis of the expression level of mRNA encoding for extracellular matrix and adhesion proteins. The exposure to CW, ref CW and PW laser modulations had no effect on the expression of glycoprotein laminin a1 (A) and cadherin 1 (B). PW Mode irradiation increased integrin a5 mRNA (C, Statistical analysis: one way ANOVA, Dunnett's multiple comparison test $\left.{ }^{*} p<0.05\right)$, while the ref CW decrease its expression. (Statistical analysis: one way ANOVA, Dunnett's multiple comparison test $\left.{ }^{*} p<0.05\right)$. PW also increased collagen type1a1 mRNA (D, Statistical analysis: one way ANOVA, Dunnett's multiple comparison test * $p<0.05$ ). 
target of red and near-infrared light [33]. The wavelength used in this study was $670 \mathrm{~nm}$, one of the four suggested "active zones" (peak positions between 667.5 and 683.7 $\mathrm{nm})$ for LLLT [33]. This corresponds to the absorption spectrum of oxidized cytochrome c oxidase [33], leading to improvement in electron transport, increased mitochondrial membrane potential (MMP), and greater ATP production [15]. Wavelengths lying between 650 and 680 $\mathrm{nm}$ also induced a significant up-regulation of gene expression in pathways involved in mitochondrial energy production and antioxidant cellular protection [34,35]. In previous studies, it was demonstrated that this ULLL protects cells from mitochondria-mediated cell death [26]. It is reported herein that mitochondria dynamics is influenced by pulsed photostimulation, and this is a quite significant result. Indeed, while this is a known phenomenon in plant cells [36], the light-dependent redistribution of mitochondria along actin or microtubule has been much less explored in mammalian cells. The analysis was performed on confocal images using a 3D-voxel image analysis software, and the mitochondria volume detected by this analysis was according to Kaasik et al. [30]. When observed in fibroblast cultures, mitochondria morphology is found to be far from static, changing continually through the phenomena of fission and fusion within minutes. The coordination between fusion and fission contributes to the response of mammalian cells to stress, and mitochondrial bioenergetics seems to be strongly dependent on mitochondrial morphology [37]. It may thus be suggested that also the effect on mitochondria dynamics is part of the overall effect of photobiostimulation on cellular metabolism and energy balance.

In view of the therapeutic application of LLL therapy to wound healing [25] and cosmetic tissue restructuring [38], the effect of ULLL irradiation on expression profile of mRNA encoding for proteins involved in extracellular matrix composition and cell-matrix interaction was then explored. As exploratory molecular targets, and in view of data previously published by our lab [27], collagen type $1 \alpha 1$, integrin $\alpha 5$, laminin $\alpha 1$, cadherins were investigated in irradiated fibroblasts. Collagen type $1 \alpha 1$ is produced from the MEF and represents $90 \%$ of total collagen in most connective tissues; integrin $\alpha 5$ is responsible for binding macromolecules to the matrix and is involved in angiogenesis; laminin $\alpha 1$ is the glycoprotein responsible for the binding to the extracellular matrix; cadherins are transmembrane proteins that mediate cell-cell adhesion in animals. By using a real-time PCR, it was shown that the expression level of mRNA encoding for collagen type $1 \alpha 1$ and integrin $\alpha 5$, but not laminin $\alpha 1$ and cadherin 1 , is upregulated by pulsed, but not by continuous ULLL irradiation.

It is well established that collagen production by fibroblasts is affected by LLLT in different body districts, such as cartilage [39], muscle [40], mucosa [41], large vessel walls [42], when used in the red-near infrared wavelength, at an energy density of around $1-5 \mathrm{~J} / \mathrm{cm}^{2}$. Moreover, also gene expression profiles of genes belonging to different categories, including cytoskeleton and cell-cell interaction, is altered upon similar irradiation in human fibroblasts [43]. Expression level of mRNAs and/or proteins belonging to the large integrine family are also affected by LLL irradiation, as found in bone [44] and in human adipose derived stem cells [45]. In our study, a comparable wavelength $(670 \mathrm{~nm})$ was used, but at a dose about a thousand times lower $\left(4.3 \mathrm{~mJ} / \mathrm{cm}^{2}\right)$ than in the above-mentioned studies.

\section{Conclusions}

These date are part of a large study aimed to highlight the affect of photostimulation by LLLT on different cellular functions. From these results we can conclude that pulsatility, but not energy density, is crucial in regulating the expression level of collagen I and integrin $\alpha 5$ in fibroblasts. This regulation could be also part of the reshaping effect of ULLL irradiation in fibroblasts [26] and of HeLa cell attachment in vitro [46,47]. However, dose-response experiments are still necessary, such as the analysis of the effect of different wavelength, to better characterize the biological impact of photostimulation by LLLT.

\section{Competing interests}

The authors declare that they have no competing interests.

\section{Authors' contributions}

AG: cell biology experiments, immunocytochemistry and image analysis. LL: laser emission mode design. MA: RT-PCR experiments. RT: RT-PCR experiments. VAB: RT-PCR experiments. LG: study design and statistical analysis. LC: study design e manuscript preparation. All authors read and approved the final manuscript.

\section{Acknowledgment}

The study was supported by RGMD SpA, which made the devices available at no cost, within the framework of an Italian Government Grant (MedTech Project Protocol 3068 DSPAR/2004). The work has been carried out in IRET Foundation laboratories, Ozzano Emilia (BO), Italy.

\section{Author details}

'Department of Veterinary Medical Sciences, University of Bologna, Via Tolara di Sopra 41/E, 40064 Ozzano Emilia, Bologna, Italy. ${ }^{2}$ Health Science and Technologies Interdepartmental Center for Industrial Research (HST-ICIR), University of Bologna, Bologna, Italy. ${ }^{3}$ IRET Foundation, Ozzano Emilia, Bologna, Italy.

Received: 30 January 2014 Accepted: 26 February 2015

Published online: 24 March 2015

\section{References}

1. Tumilty S, Munn J, McDonough S, Hurley DA, Basford JR, Baxter GD. Low level laser treatment of tendinopathy: a systematic review with meta-analysis. Photomed Laser Surg. 2010;28:3-16.

2. da Silva JP, da Silva MA, Almeida AP, Lombardi Junior I, Matos AP. Laser therapy in the tissue repair process: a literature review. Photomed Laser Surg. 2010;28:17-21.

3. Maia ML, Bonjardim LR, Quintans Jde S, Ribeiro MA, Maia LG, Conti PC. Effect of low-level laser therapy on pain levels in patients with temporomandibular disorders: a systematic review. J Appl Oral Sci. 2012;20:594-602. 
4. He WL, Li CJ, Liu ZP, Sun JF, Hu ZA, Yin X, et al. Efficacy of low-level laser therapy in the management of orthodontic pain: a systematic review and meta-analysis. Lasers Med Sci. 2013;28:1581-9.

5. Kadhim-Saleh A, Maganti H, Ghert M, Singh S, Farrokhyar F. Is low-level laser therapy in relieving neck pain effective? Systematic review and meta-analysis. Rheumatol Int. 2013;33:2493-501.

6. Thornton AL, McCarty CW, Burgess MJ. Effectiveness of low-level laser therapy combined with an exercise program to reduce pain and increase function in adults with shoulder pain: a critically appraised topic. J Sport Rehabil. 2013;22:72-8.

7. Mohammed IF, Al-Mustawfi N, Kaka LN. Promotion of regenerative processes in injured peripheral nerve induced by low-level laser therapy. Photomed Laser Surg. 2007;25:107-11.

8. Chow R, Armati P, Laakso EL, Bjordal JM, Baxter GD. Inhibitory effects of laser irradiation on peripheral mammalian nerves and relevance to analgesic effects: a systematic review. Photomed Laser Surg. 2011;29:365-81.

9. Martínez de Albornoz P, Delgado PJ, Forriol F, Maffulli N. Non-surgical therapies for peripheral nerve injury. Br Med Bull. 2011;100:73-100.

10. Baratto L, Calzà L, Capra R, Gallamini M, Giardino L, Giuliani A, et al. Ultra-low-level laser therapy. Lasers Med Sci. 2011;26:103-12.

11. Tuby H, Hertzberg E, Maltz L, Oron U. Long-term safety of low-level laser therapy at different power densities and single or multiple applications to the bone marrow in mice. Photomed Laser Surg. 2013;31:269-73.

12. Bjordal JM. Low level laser therapy (LLLT) and World Association for Laser Therapy (WALT) dosage recommendations. Photomed Laser Surg. 2012;30:61-2.

13. Silveira PC, Silva LA, Fraga DB, Freitas TP, Streck EL, Pinho R. Evaluation of mitochondrial respiratory chain activity in muscle healing by low-level laser therapy. J Photochem Photobiol B. 2009:95:89-92.

14. Zungu IL, Hawkins Evans D, Abrahamse H. Mitochondrial responses of normal and injured human skin fibroblasts following low level laser irradiation-an in vitro study. Photochem Photobiol. 2009;85:987-96.

15. Huang YY, Nagata K, Tedford CE, McCarthy T, Hamblin MR. Low-level laser therapy (LLLT) reduces oxidative stress in primary cortical neurons in vitro. J Biophotonics. 2013;6:829-38.

16. Chen AC, Arany PR, Huang YY, Tomkinson EM, Sharma SK, Kharkwal GB, et al. Low-level laser therapy activates NF-kB via generation of reactive oxygen species in mouse embryonic fibroblasts. PLoS One. 2011;6:e22453.

17. Chen $\mathrm{CH}$, Hung HS, Hsu SH. Low-energy laser irradiation increases endothelial cell proliferation, migration, and eNOS gene expression possibly via PI3K signal pathway. Lasers Surg Med. 2008;40:46-54

18. Magrini TD, dos Santos NV, Milazzotto MP, Cerchiaro G, da Silva Martinho H. Low-level laser therapy on MCF-7 cells: a micro-Fourier transform infrared spectroscopy study. J Biomed Opt. 2012;17:101516.

19. Rovetta G, Monteforte $P$, Baratto L, Franchin F. Joint involvement patterns in nodal versus erosive osteoarthritis of the hands. Int J Tissue React. 2004;26:39-42.

20. Gallamini M. Treating balance disorders by ultra-low-level laser stimulation of acupoints. J Acupunct Meridian Stud. 2013;6:119-23.

21. Giuliani A, Fernandez M, Farinelli M, Baratto L, Capra R, Rovetta G, et al. Very low level laser therapy attenuates edema and pain in experimental models. Int J Tissue React. 2004;26:29-37.

22. Lorenzini L, Giuliani A, Giardino L, Calzà L. Laser acupuncture for acute inflammatory, visceral and neuropathic pain relief: An experimental study in the laboratory rat. Res Vet Sci. 2010;88:159-65.

23. Torri S, Weber JB. Influence of Low-Level Laser Therapy on the Rate of Orthodontic Movement: A Literature Review. Photomed Laser Surg. 2013;31:411-21

24. Avci P, Nyame TT, Gupta GK, Sadasivam M, Hamblin MR. Low-level laser therapy for fat layer reduction: a comprehensive review. Lasers Surg Med. 2013:45:349-57.

25. Peplow PV, Chung TY, Baxter GD. Photodynamic modulation of wound healing: a review of human and animal studies. Photomed Laser Surg. 2012;30:118-48.

26. Giuliani A, Lorenzini L, Gallamini M, Massella A, Giardino L, Calzà L. Low infra red laser light irradiation on cultured neural cells: effects on mitochondria and cell viability after oxidative stress. BMC Complement Altern Med. 2009:9:8. doi: 10.1186/1472-6882-9-8.

27. Giuliani A, Lorenzini L, Giardino L, Calzà L. Ultra-low-level infra-red laser light irradiation on cultured fibroblasts: effects on mitochondrial and structural proteins. In: Proceedings of $8^{\text {th }}$ International Congress of the World Association of Laser Therapy: 25-28 September 2010, Bergen, Norway, vol. 1. 2010. p. 19-22. ScienceMed.
28. Hogan B, Beddington R, Costantini F, Lecy E. Manipulating the Mouse Embryo: a laboratory manual. 2nd ed. Cold Spring Harbor, NY: Cold Spring HarborLaboratory Press; 1994.

29. Tunèr J, Hode L. The New Laser Therapy Handbook. Grängesberg, Sweden: Prima Books; 2010.

30. Kaasik A, Safiulina D, Zharkovsky A, Veksler V. Regulation of mitochondrial matrix volume. Am J Physiol Cell Physiol. 2007;292:C157-63.

31. Hashmi JT, Huang YY, Sharma SK, Kurup DB, De Taboada L, Carroll JD, et al. Effect of pulsing in low-level light therapy. Lasers Surg Med. 2010;42:450-66.

32. Barolet D, Duplay $\mathrm{P}$, Jacomy $H$, Auclair M. Importance of pulsing illumination parameters in low-level-light therapy. J Biomed Opt. 2010;15:048005.

33. Karu TI, Kolyakov SF. Exact action spectra for cellular responses relevant to phototherapy. Photomed Laser Surg. 2005;23:355-61.

34. Karu TI, Pyatibrat LV, Kolyakov SF, Afanasyeva NI. Absorption measurements of a cell monolayer relevant to phototherapy: reduction of cytochrome c oxidase under near IR radiation. J Photochem Photobiol B. 2005;81:98-106.

35. Lee CS, Kim YJ, Ko HH, Han ES. Synergistic effects of hydrogen peroxide and ethanol on cell viability loss in PC12 cells by increase in mitochondrial permeability transition. Biochem Pharmacol. 2005;70:317-25.

36. Islam MS, Niwa Y, Takagi S. Light-dependent intracellular positioning of mitochondria in Arabidopsis thaliana mesophyll cells. Plant Cell Physiol. 2009;50:1032-40.

37. Chan DC. Fusion and fission: interlinked processes critical for mitochondrial health. Annu Rev Genet. 2012;46:265-87.

38. Dobke MK, Hitchcock T, Misell L, Sasaki GH. Tissue restructuring by energy-based surgical tools. Clin Plast Surg. 2012;39:399-408.

39. Alves AC, Albertini R, Dos Santos SA, Leal-Junior EC, Santana E, Serra AJ, et al. Effect of low-level laser therapy on metalloproteinase MMP-2 and MMP-9 production and percentage of collagen types I and III in a papain cartilage injury model. Lasers Med Sci. 2013;29:911-9.

40. Alves AN, Fernandes KP, Melo CA, Yamaguchi RY, França CM, Teixeira DF, et al. Modulating effect of low level-laser therapy on fibrosis in the repair process of the tibialis anterior muscle in rats. Lasers Med Sci. 2014;29:813-21.

41. Firat ET, Dağ A, Günay A, Kaya B, Karadede MI, Ersöz Kanay B, Ketani A, Evliyaoğlu O, Uysal E. The effect of low-level laser therapy on the healing of hard palate mucosa and the oxidative stress status of rats. J Oral Pathol Med 2013, doi:10.1111/jop.12106

42. Gavish L, Rubinstein C, Berlatzky Y, Gavish LY, Beeri R, Gilon D, et al. Low level laser arrests abdominal aortic aneurysm by collagen matrix reinforcement in apolipoprotein E-deficient mice. Lasers Surg Med. 2012;44:664-74.

43. Zhang Y, Song S, Fong C-C, Tsang C-H, Yang Z, Yang M. cDNA microarray analysis of gene expression profiles in human fibroblast cells irradiated with red light. J Invest Dermatol. 2003;120:849-57.

44. de Souza Merli LA, de Medeiros VP, Toma L, Reginato RD, Katchburian E, Nader $\mathrm{HB}$, et al. The low level laser therapy effect on the remodeling of bone extracellular matrix. Photochem Photobiol. 2012;88:1293-301.

45. de Villiers JA, Houreld NN, Abrahamse H. Influence of low intensity laser irradiation on isolated human adipose derived stem cells over 72 hours and their differentiation potential into smooth muscle cells using retinoic acid. Stem Cell Rev. 2011;7:869-82.

46. Karu TI, Pyatibrat LV, Kalendo GS. Cell attachment modulation by radiation from a pulsed light diode (lambda $=820 \mathrm{~nm}$ ) and various chemicals. Lasers Surg Med. 2001;28:227-36.

47. Karu T, Pyatibrat L. Gene expression under laser and light-emitting diodes radiation for modulation of cell adhesion: Possible applications for biotechnology. IUBMB Life. 2011;63:747-53. 